\title{
Construction Innovation: Inter-firm Network as Antecedent Factor with Effect on Organizational Performance
}

\author{
Yee Lin Lee, Hamzah Abdul-Rahman and Chen Wang \\ Faculty of Built Environment, University of Malaya, 50603 Kuala Lumpur, Malaysia \\ cvelyn@gmail.com, arhamzah@um.edu.com,derekisleon@gmail.com
}

\begin{abstract}
The literature on innovation, in the context of small construction firms, is scattered and still remain in its embryonic stage in the development of theories and models. The contribution of interfirm relationships to innovation and organizational performance in these firms are examined here through 159 survey data from Malaysia. We find that prioritising relationship-building strategies is relevant in facilitating innovation implementation and enhanced organizational performance within the small project-based firms. The findings implied that firms with limited resources and capabilities could expect a more significant improvement of their organizational performance, if they encourage a high level of inter-networks and innovation activities.
\end{abstract}

Index Terms - Construction Innovation, small firms, inter-firm linkages, construction, firm performance

\section{Introduction}

Over years, scholars have increasingly acknowledged innovation as the necessity for organizations to prosper or survive in a dynamic environment $[1,2]$ and therefore, the essential of competitive success and industrial evolution [3, 4, $5,6]$. Construction firms being innovative in the development and/or implementation of new ideas, products, processes or practices could bring about increased organizational performance $[7,8,9]$ and project enhancement $[10,11]$.

To date, the research attention of innovation given to small firms are limited [13, 14] and the dynamics of the correlation between innovation and small firm performance remains ambiguous. Such entrepreneurial spirit is especially important to drives a firm to be flexible in pursuing inter-firm relationships that in turn facilitates the access to key external resources, therefore, overcome the problems of transferring knowledge and learning experiences between the project and firm [12].

Hence, this study aims to extend and expand existing research, which are mainly drawn from analysis on large firms, through understanding their use of inter-firm linkages with external firms and the implications of such relationship may have for learning and innovation. The remainder of the paper is organized as follows. Section 2 reviews the construction innovation literature, which serves as the theoretical foundations for the hypotheses proposed. Section 3 presents the data and statistical methods used to test the hypotheses. The results of the study are discussed and presented in section 4 , which then summarizes and concludes the article.

\section{Inter-firm networks, innovation and firm performance}

A. Inter-firm networks and innovation

The innovation performance of construction is generally perceived as underperforming [15] where the major impediment is its continuous fragmentation [16, 17]. The industry is fragmented by project-based firms with temporary relations with external partners, therefore aggravating further the challenges of producing assets that are large, unique, complex, long-lasting, expensive and risky [18]. It is against this backdrop that small firms struggle.

For small firms with limited resources, innovation seems particularly vital for their competitive advantage and survival [8]. However, innovation is typically said to be a resource intensive activity, and hence can be difficult for them to undertake [14]. Yet, there were suggestions points out that some resource-constrained firms are able to overcome the resource disadvantages of their size and grow faster than their peers by successfully driving project innovations. By strategically exploiting its external environment, small firms could build up their strong internal capabilities and develop innovations with characteristics appropriate to its environment, capabilities and likely projects [13].

Considering the peculiarities of the industry which is characterized by the segregated nature of construction activities, various studies $[19,20]$ shown that networking relations would play a crucial role in favouring innovation process. A climate of integrated effort and shared values among project participants greatly reduce the fragmentation among team members, and therefore, contribute to the generation and successful development of innovation [16, 21, 22]. The social capital, such as information, knowledge and resources [23] embedded in such networks are particularly conducive for continuous innovativeness and enhanced SME performance [24, 25].

Despite the proven positive impact of networks on innovation, empirical evidence into the relationship between social capital and SME performance is inconclusive in that "research has largely not accounted for the mediating process steps that translate social capital into organizational performance outcomes" [26; p. 157]. Research on small firms' networking and their contribution to construction projects innovation do not reach a clear conclusion. Hence, we postulated the following hypotheses (see Fig. 1): 
H1a. The greater the inter-firm network, the greater the product innovation.

H1b. The greater the inter-firm network, the greater the process innovation.

\section{B. Innovation and firm performance}

In construction literature, innovation is typically defined as the actual use of a nontrivial change and improvement in a process, product or system that is novel to the institution developing the change [16]. Also, it is described as 'the first use of a technology within a construction firm either in the process or in the product [27; p. 884].' It is ubiquitous regarding the technical advancements and their significant impact on projects and organizations of successful innovation implementation. The results of the technological process of innovation, which is materialized in product- and processrelated innovations, became vital with the increasing technical complexity in projects and international competition [28].

This paper accordingly focuses on technological innovation to complements the innovation literature within the context of small construction firms. While it is widely agreed that innovation leads to positive project outcomes [8], nevertheless very limited studies address its impact on organizational performance. Innovation are usually undertaken by the construction firms and implemented on construction projects [11, 19] and that innovative activities are generally pervasive throughout all on-going activities of a firm and are difficult to isolate and evaluate [29]. These suggest that the firm is at the centre of an enabling network of the industry and therefore, firm can be a suitable unit of consideration for this research's focus on construction innovation. Based on the above discussion, we hypothesize (see Fig. 1) the following:

$\mathrm{H} 2 \mathrm{a}$. Product innovation will positively influence firm performance.

$\mathrm{H} 2 \mathrm{~b}$. Process innovation will positively influence firm performance.

\section{Data and Variables}

\section{A. Sample}

Earlier works on small construction firms are dominant in using qualitative method for answering inquiry in the innovation management field $[13,14]$. To comprehend their contribution, the samples of current study were firm's managing director/senior manager. Excluding the microbusiness (with fewer than ten workers), the questionnaires

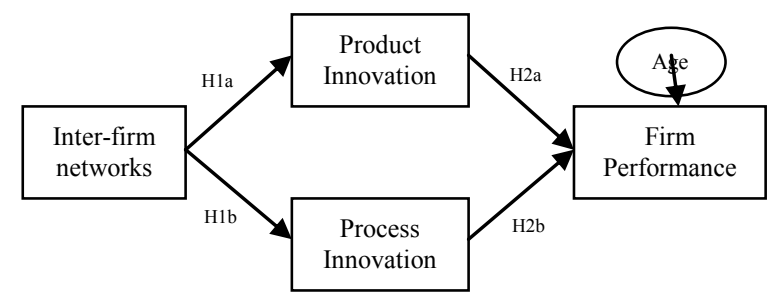

Fig. 1. Conceptual model were distributed to 761 small-sized contracting companies throughout Kuala Lumpur. Prior to main distribution of the questionnaires, a preliminary test of their design was carried out to further improve the clarity of the content. Fieldwork on the final questionnaire occurred during July-October 2013. To further improve the response rate, follow-up telephone calls were made to request participation. Of the 174 responses obtained, 17 were subsequently eliminated as invalid owing to incomplete or incorrectly completed issue. The final useable questionnaires were 157 , which provided the final effective response rate of $21 \%$.

\section{B. Measure}

The measurement items are formulated on the basis of thorough review of the literature and pre-tested with 15 competitive small constructing companies located in Kuala Lumpur. The questionnaires comprise four main constructs. The scale developed by authors as in $[30,31]$ was modified to measure inter-firm networks, which composed of eight items in total. To assess innovation, this study adopts some of the innovation measures developed by authors as in [32, 33]. The innovation construct measures process innovation and product innovation and has 8 items. Finally, this study adopts the work of author as in [34] for the firm performance measure, which comprises 7 items. Also, we included firm age to control for the endogenous variables.

\section{Results}

To test the conceptual model, structural equation modeling was employed using the partial least squares (PLS) approach [35]. This tool is particularly suitable for small samples with complex models; a prediction-oriented method that does not require strong theory [36]. In this regard, developing both measurement and structural models are important to adequately formulate the hypothesized relationships within the proposed model [35], as presented below.

\section{A. Measurement model}

As recommended [37], the individual reliability of the items was evaluated using factor loadings of $\geq 0.707$. Table 1 shows that factor loadings for all the constructs in the conceptual model exceed this minimum value. Further, the construct reliability is determined by analysing joint reliability. 0.8 is suggested as a suitable level for this indicator [38]. Values of this index exceed the minimum for all the constructs (Table 1). Next, to assess convergent validity, the average variance extracted (AVE) is analysed. As recommended [39], AVE should be $\geq 0.5$ for all the constructs (Table 1). Eventually, to check the discriminant validity, the AVE for all latent constructs has to be compared with reflective indicators, and that the square root of the AVE must be greater than correlations between the constructs. 
Table 1 Measurement model results

\begin{tabular}{|c|c|c|c|c|c|}
\hline Factors & SL & SE & t-value ${ }^{a}$ & $\mathrm{CR}$ & $\mathrm{AVE}^{\mathrm{b}}$ \\
\hline Inter-firm network (molecular 2nd-order factor) & & & & 0.823 & 0.794 \\
\hline Customers/Clients & 0.852 & 0.043 & 17.189 & & \\
\hline Suppliers of components, equipment and software & 0.846 & 0.047 & 16.314 & & \\
\hline Competitors & 0.728 & 0.051 & 13.168 & & \\
\hline Experts and consultancy firms & 0.785 & 0.067 & 9.821 & & \\
\hline R \& D firms or laboratories & 0.723 & 0.057 & 11.950 & & \\
\hline Universities or centres of higher education & 0.726 & 0.072 & 8.230 & & \\
\hline Public and non-profit research organizations & 0.759 & 0.075 & 7.431 & & \\
\hline Firms outside your industry & 0.744 & 0.074 & 2.629 & & \\
\hline Product innovation & & & & 0.787 & 0.730 \\
\hline Prod1 & 0.715 & 0.035 & 22.795 & & \\
\hline Prod2 & 0.813 & 0.046 & 17.407 & & \\
\hline Prod3 & 0.878 & 0.027 & 31.665 & & \\
\hline Prod4 & 0.821 & 0.033 & 24.463 & & \\
\hline Process innovation & & & & 0.937 & 0.788 \\
\hline Proc1 & 0.881 & 0.030 & 29.044 & & \\
\hline Proc2 & 0.906 & 0.019 & 47.955 & & \\
\hline Proc3 & 0.911 & 0.021 & 42.466 & & \\
\hline Proc4 & 0.853 & 0.032 & 26.139 & & \\
\hline Firm performance & & & & 0.959 & 0.768 \\
\hline FP1 & 0.839 & 0.043 & 19.441 & & \\
\hline FP2 & 0.896 & 0.025 & 35.353 & & \\
\hline FP3 & 0.852 & 0.029 & 29.634 & & \\
\hline FP4 & 0.871 & 0.034 & 25.595 & & \\
\hline FP5 & 0.892 & 0.028 & 31.416 & & \\
\hline FP6 & 0.881 & 0.030 & 29.606 & & \\
\hline FP7 & 0.903 & 0.025 & 36.303 & & \\
\hline Age & 1.000 & 0.000 & 0.000 & 1.000 & 1.000 \\
\hline
\end{tabular}

Notes: SL, standardized loading; SE, standard error; CR, composite reliability; VIF, variance inflation factor; n.a., not applicable.

${ }^{a}$ Absolute t-values greater than 1.645 are one tailed significant at $5 \%$

${ }^{\mathrm{b}}$ Percentage of item variance explained by the latent variable.

\section{B. Structural model}

The result shown in Table 2 summarizes the results for the path models. Inter-firm network is the exogenous construct, with product and process innovations as intermediate endogenous constructs, and firm performance as endogenous construct. The t-values (Table 2) were calculated using a bootstrap resampling procedure with 500 subsamples [36]. The coefficient of determination $\left(\mathrm{R}^{2}\right.$ value $)$ of $0.75,0.50$ and 0.25 for endogenous constructs can be respectively described as substantial, moderate, or weak [35]. The $\mathrm{R}^{2}$ for the performance variable indicates that the conceptual model proposed explains $59.8 \%$ of the variance of the construct, which is a very satisfactory level of predictability.

Table 2 Structural equation model results

\begin{tabular}{|c|c|c|c|}
\hline & $\begin{array}{c}\text { Standardized } \\
\text { coefficient }\end{array}$ & t-value & Conclusion \\
\hline \multicolumn{4}{|l|}{ Hypothesized links } \\
\hline $\begin{array}{l}\text { Inter-firm networks } \\
\rightarrow \text { Product innovation }\end{array}$ & $0.63^{* * * * *}$ & 9.5436 & $\begin{array}{c}\text { H1a } \\
\text { supported }\end{array}$ \\
\hline $\begin{array}{l}\text { Inter-firm networks } \\
\rightarrow \text { Process innovation }\end{array}$ & $0.38^{* * * * * *}$ & 3.9379 & $\begin{array}{c}\text { H1b } \\
\text { supported }\end{array}$ \\
\hline $\begin{array}{l}\text { Product innovation } \\
\rightarrow \text { Firm performance }\end{array}$ & $0.53^{* * * * *}$ & 4.8949 & $\begin{array}{c}\mathrm{H} 2 \mathrm{a} \\
\text { supported }\end{array}$ \\
\hline $\begin{array}{l}\text { Process innovation } \\
\rightarrow \text { Firm performance } \\
\text { Non-hypothesized links }\end{array}$ & $0.78^{* * * * * *}$ & 11.4190 & $\begin{array}{c}\mathrm{H} 2 \mathrm{~b} \\
\text { supported }\end{array}$ \\
\hline $\begin{array}{l}\text { Age } \rightarrow \text { Firm performance } \\
\text { Goodness-of-fit statistics }\end{array}$ & $0.02^{\mathrm{n} . \mathrm{s}}$ & 0.3848 & \\
\hline $\mathrm{R}^{2}$ & $0.59^{*}$ & & \\
\hline
\end{tabular}

To assess the hypothesized relationships among the constructs, the path coefficients $(\beta)$ and corresponding significance levels must be analysed. As presented in Table 2, inter-firm network has a significant effect on product innovation $(\beta=0.636, \mathrm{t}=9.543)$ and process innovation $(\beta=0.375, \mathrm{t}=3.937)$, providing support for $\mathrm{H} 1 \mathrm{a}$ and $\mathrm{H} 1 \mathrm{~b}$. The effects of product innovation $(\beta=0.531, \mathrm{t}=4.894)$ and process innovation $(\beta=0.784, \mathrm{t}=11.419)$ on firm performance are also significant, giving support to supporting $\mathrm{H} 2 \mathrm{a}$ and $\mathrm{H} 2 \mathrm{~b}$, respectively. With regard to the control variable, age $(\beta=0.019$, $\mathrm{t}=0.384$ ) were not significant.

\section{Discussion and Conclusions}

This paper has addressed the question of how inter-firm network may influence construction innovation, which in turn leads to greater firm performance. The empirical results provide strong support to the hypothesized relationships as depicted in Fig. 1. Some interesting results obtained from our analysis have contributed to the literature in three ways. First, it is the first effort that focuses on the underlying processes through which technological innovations (i.e., product and process innovations) are affected by inter-firm network, as well as their influence on firm performance. Second, the findings add to the construction literature by quantitatively uncovering the significance of inter-firm networks to innovation and organizational performance, in the context of small construction contracting firms. Finally, the research extends previous research that explored very much on project performance; we addressed the effect of technological innovations on the organizational performance.

In summary, this paper reports an innovativeness study in 
the Malaysian construction industry, which it not only reveals the contribution of networks to innovation and organizational performance, but also points out that different type of innovations exerts different impact on performance aspects. The findings support the claim in other industries [23] that innovation has a positive and significant impact on the performance and growth in the small business sector of the construction industry. We complement the existing study by using a quantitative approach to gain a comprehensive picture of to what extent inter-firm networks support innovation and organizational performance. Further, investigating the nature and impact of non-technological aspects of innovation should be considered, to provide a holistic approach to the future line of research.

\section{Acknowledgment}

This paper arose from research by PPP (Postgraduate Research) Project funded by the Institute of Research Management \& Monitoring of University of Malaya.

\section{References}

[1] J.M. Howell and C.A. Higgins, "Champions of technological innovation," Administrative Science Quarterly, 35(2), 317-341, 1990.

[2] F. Damanpour and M. Schneider, "Phases of the adoption of innovation in organizations: effects of environment, organization and top managers," British Journal of Management, 17(3), 215-236, 2006.

[3] R. Nelson and S. Winter, An evolutionary theory of economic change, Cambridge, MA: Belknap Press, 1982.

[4] M.E. Porter, Competitive Strategy: Techniques for Analyzing Industries and Competitors, Free Press, New York, 1980.

[5] J.A. Schumpeter, The theory of economic development, Cambridge, MA: Harvard University Press, 1934.

[6] J.M. Utterback, Mastering the dynamics of innovation: how companies can seize opportunities in the face of technological change, Boston: Harvard Business School Press; 1994.

[7] C.O. Egbu, J. Henry, G.R. Kaye, P. Quintas, T.R. Schumacher and B.A. Young, "Managing organizational innovation in construction. In: Proceedings of the $14^{\text {th }}$ Annual Conference of the Association of Researchers in Construction Management”, ed. Hughes W.ARCOM, 605-614, 1998.

[8] M.G. Sexton and P.S Barrett, Performance-based building and innovation: Balancing client and industry needs, Building Research and Information, 33(2), 142-148, 2005.

[9] K. Panuwatwanich, R.A. Stewart and S. Mohamed, Validation of an empirical model for innovation diffusion in Australian design firms. Construction Innovation: Information, Process, Management, 9(4), 449-467, 2008.

[10] C.J. Madewell, Innovative solutions to the challenges of heavy civil projects, in Tatum, C.B. (ed.) Construction Innovation: Demands, Successes and Lessons, Proceedings of a session, ASCE Convention in Seattle, WA, ASCE, Reston, VA, 8-10 April, 1986, pp. 11-17.

[11] E.S. Slaughter, Implementation of construction innovation, Building Research and Information, 28(1), 1-17, 2000.

[12] I. Drejer and A.L. Vinding, Organisation, 'anchoring' of knowledge, and innovative activity in construction, Construction Management and Economics, 24(9), 921-931, 2006.

[13] K. Manley, Against the odds: Small firms in Australia successfully introducing new technology on construction projects, Research Policy 37, 1751-1764, 2008.

[14] P.S. Barrett and M. Sexton, Innovation in small, project-based construction firms, British Journal of Management, 17, 331-346, 2006.

[15] R. Reichstein, A. Salter and D. Gann, Last among equals: a comparison of innovation in construction, services and manufacturing in the UK, Construction Management and Economics, 23(6), 631-644, 2005.

[16] E.S. Slaughter, Models of construction innovation, Journal of Construction Engineering and Management, 124(3), 226-232, 1998.
[17] C. Harty, Innovation in construction: a sociology of technology approach, Building Research and Information, 33(6), 512-522, 2005.

[18] C.H. Nam and C.B. Tatum, Major characteristics of constructed products and resulting limitations of construction technology, Construction Management and Economics, 6, 133-148, 1998.

[19] G. Winch, Zephyrs of creative destruction: understanding the management of innovation in construction, Building Research and Information, 26(4), 268-279, 1998.

[20] D.M. Gann and A.J. Salter, Innovation in Project Based, Service Enhanced Firms: The Construction of Complex Products and Systems. Research Policy, 29, 955-972, 2000.

[21] C.B. Tatum, Potential mechanisms for construction innovation. ASCE J. of Construction Engineering and Management, 112(2), 178-191, 1986.

[22] B.A.G. Bossink, Managing drivers of innovation in construction networks. ASCE J of Const. Eng. and Management, 130(3), 337-345, 2004.

[23] S. Lee, P. Wong and C. Chong, Human and social capital explanations for R\&D outcomes. IEEE Transactions on Engineering Management, 52(1), 59-68, 2005.

[24] L. Pittaway, M. Robertson, K. Munir, D. Nenyer and A. Neely, Networking and Innovation: A Systematic Review of the Evidence, International Journal of Management Reviews, 5/6(3\&4), 137-168, 2004.

[25] R, van Wijk, J.J. Jansen and M.A. Lyles, Inter- and IntraOrganizational Knowledge Transfer: A Meta-Analytic Review and Assessment of Its Antecedents and Consequences, J. of Manage. Studies 45, 830-853, 2008.

[26] I. Maurer, V. Bartsch and M. Ebers, The Value of Intraorganizational Social Capital: How It Fosters Knowledge Transfer, Innovation Performance and Growth, Organization Studies 32(2), 157-185, 2011.

[27] D.O. Pedersen, "The Economics of Innovation in Construction", In Katavic, M. (ed.), Economic management of innovation, productivity and quality in construction: CIB W 55 Building Economics 7th International Symposium, September 4-7, 1996, pp.158-184, Faculty of Civil Engineering University of Zagreb, Zagreb, Croatia.

[28] C.B. Tatum, Technology and competitive advantage in civil engineering. Journal of Professional Issues in Engineering, 114(3), 256-264, 1988.

[29] A. Manseau and G. Sedean, Innovation in construction: an international review of public policies, Spon Press, London, 2001.

[30] S. Gronum, M.-L. Verreynne and T. Kastelle, The role of networks in small and medium-sized enterprise innovation and firm performance. $J$. of Small Business Manage., 50(2), 257-282, 2012.

[31] L.A.G. Oerlemans and J. Knoben, Configurations of knowledge transfer relations: An empirically based taxonomy and its determinants. J. Eng. Technol. Manage. 27, 33-51, 2010.

[32] F. Mavondo, J. Chimhanzi, and J. Stewart, Learning orientation and market orientation: Relationship with innovation, human resource practices and performance. European J. of Marketing, 39(11/12), 1235-1263, 2005.

[33] M. Song and J. Xie, Does innovativeness moderate the relationship between cross-functional integration and product performance? Journal of International Marketing, 8(4), 61-89, 2000.

[34] Y.-H. Li, J.-W. Huang and M.-T. Tsai, Entrepreneurial orientation and firm performance: The role of knowledge creation process. Industrial Marketing Management 38, 440-449, 2009.

[35] W.W. Chin, Issues and opinion on structural equation modelling. MIS Quarterly, 22(1) xvii-Xv, 1998.

[36] W.W. Chin and P.R. Newsted, "Structural equation modeling analysis with small samples using partial least squares", In R. Hoyle (Ed.), Statistical strategies for small samples research, 1999, pp. 307-341, Newbury Park, CA: Sage Publications.

[37] E.G. Carmines and R.A. Zeller, Reliability and validity assessment. Newbury Park, CA: Sage Publications, 1979.

[38] J. Nunnally, Psychometric theory. New York: McGraw-Hill, 1978.

[39] C. Fornell and D. Larcker, Evaluating structural equation models with unobservable variables and measurement error. J. of Marketing Research, 18, 39-50, 1981. 